\title{
INHIBITION IN PENICILLIN-INDUCED EPILEPTIC FOCI ${ }^{1}$
}

\author{
T.E. ANDERSON ${ }^{2}$ and L T. RUTLEDGE \\ Neuroscience Program, University of Michıgan, Ann Arbor, Mıch. 48109 (U.S A)
}

(Accepted for publication: September 8, 1978)

As an acute model of focal epilepsy, the penicillin focus has been widely utilized since the initial report by Walker and Johnson (1945). However, the cellular mechanisms responsible for the epileptogenic effect of penıcıllın remain poorly understood. A characteristic feature of penicillin-induced epleptıc foci is the paroxysmal depolarizing shift (PDS), which may be observed in many of the neurons in the focus (Matsumoto and Ajmone Marsan 1964). The PDS is well correlated temporally with the interictal spike seen in the electrocorticogram and appears to be a giant excitatory postsynaptic potential (EPSP) (Matsumoto et al. 1969; Prince 1969). Attempts to explain the basis for the PDS have led to investigation of the effect of penicillin on inhibitory processes in the cortex. Curtis et al. (1972) demonstrated that pentcillın increased the firing rate of unidentified neurons in cat postcruciate cortex and antagonized the inhibitory action of gamma-aminobutyric acid (GABA) on the discharge of those neurons.

Stıll, the effect of penicillin upon inhibitory processes in mammalian cortex remains an open question. While inhibitory postsynaptic potentials (IPSPs) are still present in epileptic foci (Dichter and Spencer 1969; Matsumoto et al. 1969; Prince 1969), their func-

\footnotetext{
1 This research was supported by Grants MH 14279 and NINCDS 04119. Data reported here were also submitted in partial fulfilment of the requirements for the Ph.D. degree in Neurosciences at the University of Michigan by T E A.

2 Present address Dept. of Zoology, University of Texas, Austin, Tex. 78712, U.S.A.
}

tional effectiveness may be imparred. To attack more directly the question of functional mhibition in the cortex, Van Duyn et al. (1973) used the surface negative wave evoked by peduncular stimulation as an indicator of effectiveness of recurrent inhibition in the pericruciate cortex of cats. Humphrey (1968) demonstrated that the surface negative (SN-wave) component of the complex potential recorded at the surface of pericruciate cortex was a reflection of postsynaptic potentials (PSPs) generated through recurrent inhibitory pathways. Van Duijn et al. (1973) showed that in barbiturate anesthetized cats the amplitude of the SN-wave diminished over time subsequent to topical application of penicillın. The time course for maximal decay of amplitude was comparable to that for development of an epileptic focus. and the amplitude would slowly recover after the penicillun was removed from the cortex. Pen1cillin which had been deactivated by pre-incubation with penicillinase had no effect on $\mathrm{SN}$ wave amplitude. The lemniscal response was unaffected, as were the late component evoked by peduncular stimulation (thought to represent excitatory events) and the contralateral SN-wave. The implication was that effectıveness of recurrent inhıbition was selectively reduced by penicillin and that this might be one of the bases for penicllin's epıleptogenicity. However, important questions remained which could only be answered through analysis of the phenomenon at the neuronal level. Was recurrent inhibition functionally reduced at the pyramidal cell body subsequent to penicillin application or was 
the reduced amplitude of the $\mathrm{SN}$-wave the result of some other effect of penicillin? If recurrent inhibition was reduced by peniculin, what was the most likely mechanism? The goal of the present research was to determine the most likely of 4 alternative explanations for the results of Van Duijn et al. (1973). The furst mechanism which may be postulated is that penicillin acts on the deep pyramidal cells axons, their recurrent collaterals or the synapses of these axons onto inhibitory interneurons. This is rather unllkely, since it has been determined that penicillin diffuses passively and that $95 \%$ of the labeled drug is confined to layers I-III of the cortex at the onset of interictal spiking (Pedley and Noebels 1976). A second alternative is that the responsiveness of the inhibitory interneurons is reduced specifically through an effect of pen1cillin on the neuronal membrane. Thurd, penicillin may block transmission at the inhibitory synapses onto pyramidal tract cells (and possibly other neurons also). Finally, inhibitory pathways may not be specifically blocked by penicillin at all, but rather the drug may act to enhance excitatory input. An experimental design was chosen which could distinguish between these alternatives.

\section{Materials and Methods}

Experiments were performed on adult cats initially anesthetized with ether. After tracheostomy and femoral vein cannulation, alphachloralose (in propylene glycol, $35 \mathrm{mg} / \mathrm{kg}$ 1.v.) was administered. Ether was withdrawn as soon as chloralose anesthesia was effective. Cisternal drainage was performed to help minimize cortical pulsations. After a wide unilateral craniotomy, exposing the enture precruciate cortex, the dura was reflected and the exposed cortex covered with warm mineral oil, maintained at $38.5^{\circ} \mathrm{C}$. Animals were 1 mmobilızed with gallamine triethıodide and artificially respurated to maintain expired $\mathrm{CO}_{2}$ at $3-4 \%$. A solution of $5 \%$ dextrose in salıne was administered at a rate of $5 \mathrm{ml} / \mathrm{h}$.
Body core temperature was maintained at $37-38^{\circ} \mathrm{C}$.

A bipolar stimulating electrode, insulated except for $0.5 \mathrm{~mm}$ at the tip and with tip separation of $2 \mathrm{~mm}$, was placed in the ipsilateral cerebral peduncle at coordinates $F$ 5.5-6, $\mathrm{L} 4-5$ and $\mathrm{H}-4$ to -6 , according to the atlas of Jasper and Ajmone Marsan (1954) Position of the electrode was verified electrophysiologically by appearance of $a$ and $b$ waves at the cortical surface following single stimulus pulses to the peduncle (Stefanis and Jasper 1964; Humphrey 1968). Stımulus parameters were of $0.05 \mathrm{msec}$ duration and $0.8 \mathrm{~mA}$ intensity and clearly did not activate lemniscal fibers with the electrode positioned in the peduncle. The $\mathrm{SN}$-wave was evoked by stımulation of the peduncle with a brief train of pulses ( 3 pulses, intraburst frequency 300 $\mathrm{c} / \mathrm{sec}, 0.05 \mathrm{msec}$ duration, $0.8 \mathrm{~mA}$ intensity) and the site of maximal SN-wave amplitude was determined using a platinum ball electrode. Neuronal activity was sampled in this area using tungsten microelectrodes which allowed simultaneous recording of 2-4 neurons.

A monopolar platinum ball stimulating electrode was placed on the surface of the cortex 2-3 $\mathrm{mm}$ anterior to the site of microelectrode penetration, and a pair of needle electrodes inserted into the contralateral forepaw footpad. Epicortical stimulus was of 0.8 mA intensity, 0.2 msec duration, while intensity for forepaw stımulation was determined prior to immobilızation as slightly suprathreshold for just discernible foot twitch maintaining duration at $0.2 \mathrm{msec}$.

Spontaneous activity and evoked responses of neurons to peduncular stimulation (to test recurrent inhibition at pyramidal tract cells, Humphrey 1968), epicortical stimulation (to test local inhibitory circuits, Krnjević 1966a, b) and forepaw footpad stimulation (to test afferent pathways) were displayed on an oscilloscope and recorded on film for later analysis. Only neurons exhibiting no signs of injury discharge were studied.

A neuron was categorized as a pyramidal 
tract (PT) neuron if it responded with a short (less than $1.2 \mathrm{msec}$ ) and constant latency to single shock stimulation of the peduncle and would follow stimulation to at least 100 $\mathrm{c} / \mathrm{sec}$. Non-PT cells were further categorized by spontaneous and forepaw stimulation evoked furing behavior as bursting (B-NPT) or not (NPT) and the latency of an excitatory response to peduncular stimulation was compared to the SN-wave peak latency for possible involvement of the neuron in recurrent inhıbitory pathways.

A $1 \mathrm{~mm}$ cube of gelfoam was soaked in a freshly prepared solution of potassium-penicillin in saline, $80,000 \mathrm{U} / \mathrm{ml}$. In no instance was the edge of the gelfoam pledget placed more than $1 \mathrm{~mm}$ distant from the site of microelectrode insertion, and the distance was typically $0.5 \mathrm{~mm}$. Spontaneous activity and response to the 3 stimuli were recorded on film immediately subsequent to penicillin application and at $5 \mathrm{~min}$ intervals therafter for at least $20 \mathrm{~min}$ after interictal spikıng appeared in the slow wave record.

In most cases, spontaneously active neurons were selected so inhibition could be assessed against a background level of activity. However, to help guard against sampling bıas, some non-spontaneously active PT cells were analyzed also. Antidromic invasion probability was used as a test for inhibition (Stefanis and Jasper 1964). Stimulus intensity was adjusted so a single pulse would result in antrdromic invasion of the neuron studied $100 \%$ of the trials. This stimulus was then used as a test stimulus, considering the $100 \mathrm{msec}$ poststımulus interval.

For spontaneously active neurons, data were analyzed from film records. A stimulus artifact suppressor enabled observation of very short latency effects by switching the microelectrode out of the recording circuit durung stimulation and supplying a constant voltage level to the preamplifier during that period; the voltage was determined by the baseline voltage level recorded from the $\mathrm{mi}$ croelectrode immediately preceding stimulation and automatically adjusted. From the film records histograms were generated for each neuron's spontaneous and evoked responses by discrimination and counting of individual action potentıals (requiring constancy within $5 \%$ for a single spike amplitude and differentiation from other spikes in the record by at least $20 \%$ ). Inhibition or excitation was defined as a deviation from the mean spontaneous count per $10 \mathrm{msec}$ by more than 1 S.E.M. (or change in antıdromic invasion probability of more than $20 \%$ ), and the 100 msec poststimulus interval was the time interval analyzed. If the maximal deviation of the histogram from the mean spontaneous count did not exceed these criteria, then the stimulus was determined to have no effect on the spontaneous discharge of the neuron.

\section{Results}

Acute epileptic foci were successfully induced in 23 cats and the activity of 84 neurons was recorded extracellularly. These neurons consisted of $22 \mathrm{PT}$ cells, 44 B-NPT cells and 18 NPT cells. Since the penicillin was applied so close to the site of microelectrode penetration all neurons were assuredly located in the active focus. The responses of the neurons to the stimul stabilized within $5 \mathrm{~min}$ after interictal spiking first appeared, and it is this stabilized pattern of responses which is reported here under the post-penicillin category. Neurons were monitored for at least 20 min and usually $1 \mathrm{~h}$ or more after interictal spiking was observed. Depth of the neurons recorded was determined from microdrive readings, and ranged from 1080 to $1860 \mu \mathrm{m}$, with a mean of $1588 \mu \mathrm{m}$. Although an attempt was made to penetrate perpendicular to the surface of the cortex for the microelectrode tracks, curvature of the cortex near the cruciate sulcus confounds the correlation of depth with cortical layer structure in the absence of histological marking and identification of recording sites. Therefore, no such correlation attempts were made. 


\section{PT neurons}

The PT neurons had slow spontaneous rates $(1-5 / \mathrm{sec})$ and 11 of the PT cells studied were not spontaneously active. Ten PT cells were followed through the development of a focus with responses of an additional 8 neurons recorded from normal cortex and of 4 from epileptic cortex without the benefit of continuous recording of the neuronal activity through the transition from normal to epleptic cortex. Since the PT cells were almost all inhibited by peduncular stimulation prior to penicillin application and have been shown to exh1bit predominantly inhibitory effects in response to pyramidal tract stimulation in other studies as well (Stefanis and Jasper 1964; Renaud and Kelly 1974a, b), observations regarding the 4 neurons whose responses were recorded only post-penicillin have been included.

The responses from one of the 10 spontaneously active PT cells are given in Fig. 1, and histograms calculated from these data are shown in Fig. 2. Histograms were calculated by averaging 2-3 film frames (for this neuron, three) of the response to each of the stimul pre- and post-penicllin. Thus, the apparent inhibition seen in the fllm records of response to peduncular and epicortical stimulation prior to application of penicillin is seen to be a deviation from the mean spontaneous activity which is 2.5 times greater than the standard error, clearly satisfying the criterion for an inhibitory effect of the stimulation. The response to forepaw stimulation 1s similarly seen to satisfy the criterion for excitation followed by inhibition. Post-stimulus effects are more obvious in histograms than in single frames due to the random distribution of spontaneous activity compared to constant latency post-stimulus effects. While the 10-20 superımposed sweeps comprising a single frame in Fig. 1 are sufficient to demonstrate an effect of stimulation, additional averaging is necessary to satisfy the statistical criteria used to define post-stimulus effects.

Similarly, post-penicillin, peduncular and epicortical stimulation did not cause signifi-

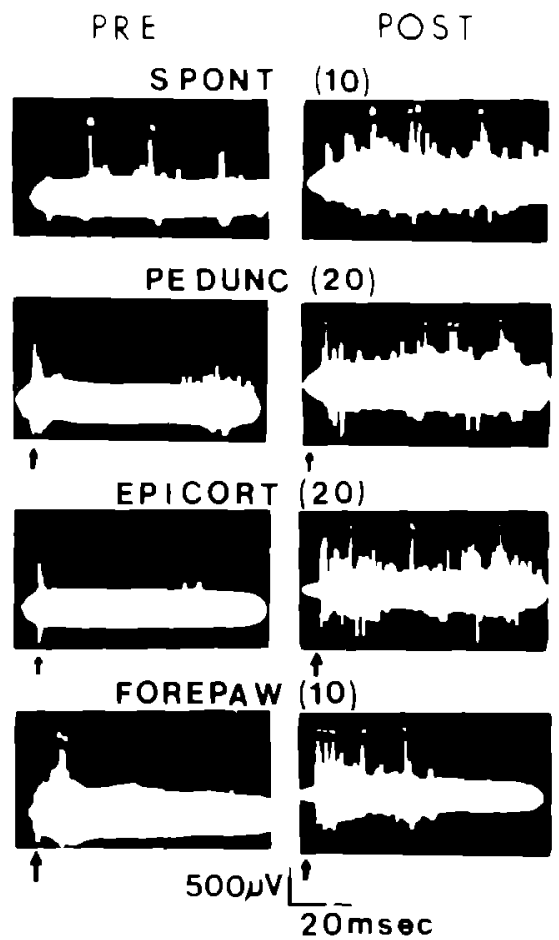

Fig 1 Post-stimulus responses of a sample PT neuron (discharge marked by dots) pre- and post-penıcillin. The number of superimposed sweeps per frame is indicated in parentheses. Pedunc., peduncular stımulation, Epicort, epicortical stımulation. Stımulus delivery is indicated by the arrow

cant deviation of neuronal firing from mean spontaneous activity, while forepaw stimulation results in an initial excitatory deviation from mean spontaneous activity 3 times the standard error.

The effects of the stimul on non-spontaneously active PT cells were determined by assessing the antidromic invasion probability of a single peduncular shock capable to invading the neuron soma $100 \%$ of the trials in the absence of a prior conditioning stimulus. (Since these neurons were mactive, collision of antidromic and orthodromic action potentials was not a complicatıon.) Utilizing the test pulse, invasion probability was measured as a function of time subsequent to the conditioning stimulus, elther peduncular, ep1cortical or forepaw footpad stimulation. Prior to penıcillnn all 6 neurons were inhibited by 

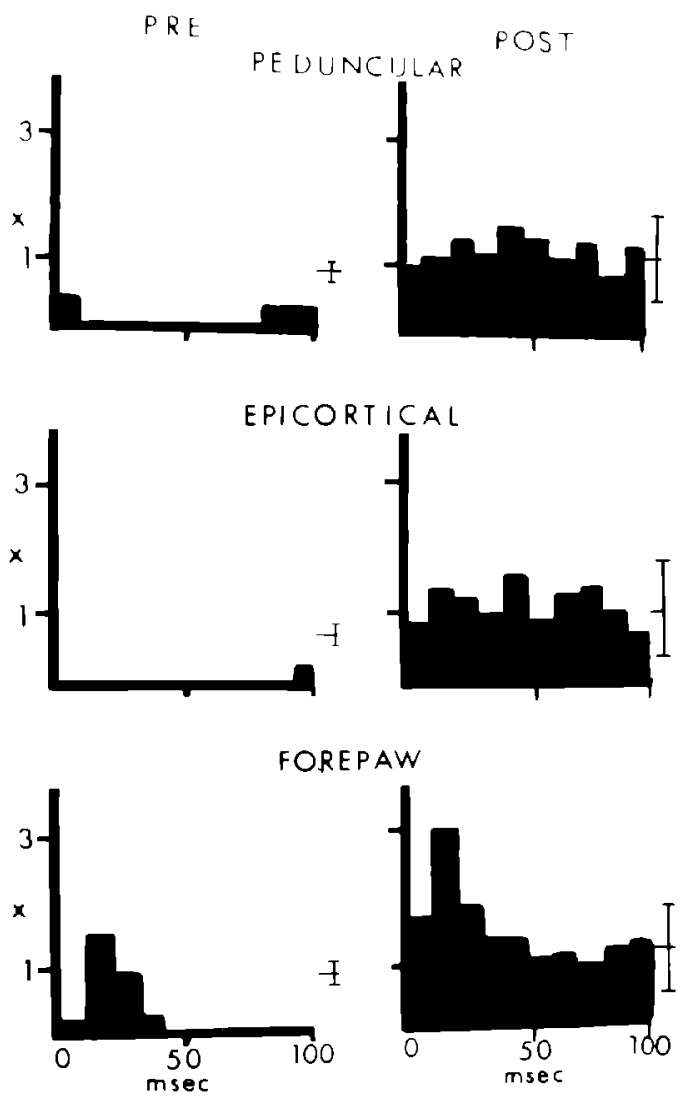

Fig. 2 Post-stımulus histograms pre- and post-penicillin derived for the PT cell shown in Fig. 1. The spontaneous rate and standard error of the mean are ind 1 cated at the right (spontaneous rate $=06$ pre-, 08 post-penicillin). Note that inhibition of PT-cell discharge, clearly evident pre-penicillın, is absent following development of the penicillin focus. peduncular stımulation, while epıcortical stimulation had a less potent inhibitory effect with two neurons inhibited and three unaffected. In the penicillin focus, neither stimulus had an effect on antidromic invasion probability. Pre-penicillin, forepaw stimulation evoked action potentials in addition to the antidromically evoked spikes, rassing the invasion probability above 1.2 , the criterion defining an excitatory effect, and the initial excitation was followed by a period of invasion probablity less than 0.8 , satisfying the criterion for inhibition. Post-penicillin, only the increased invasion probability was observed. Interpretations of the PT cell data are summarized in Table I.

The averaged responses for the 10 PT cells followed pre- through post-penicillin are shown in Fig. 3. Note the sequence of excitatıon followed by inhibitıon, pre-penicıllin, in response to forepaw stimulation, whlle later in the focus, excitation alone was observed. The time courses are consistent with interaction of excitation and inhibition in cortex pre-penicillin, with initıal excitation damped by longer latency inhibition. Loss of this later inhibition post-penicillin could result in greater excitatory deviation from mean spontaneous activity and increased duration of excitation.

$B-N P T$ cells

Thirty of these neurons (representing $68 \%$

\section{TABLE I}

Response characteristics of PT cells Data are tabulated as the number of cells in each category, both pre- and post-penıcillin. Excitation, inhibition and no effect are as defined in the text. Excit. $\rightarrow$ inhıb indicates an inıtial excitation followed by inhibition in response to the stımulus. Response characteristics of neurons recorded only pre- or post-penıcillin are given in parentheses.

\begin{tabular}{llllcr}
\hline Stimulation & & Excit & Excit. $\rightarrow$ inhib & Inhıb. & No effect \\
\hline Peduncular & Pre & $0(1)$ & $(1)$ & $10(6)$ & 0 \\
Epicortical & Post & 3 & 0 & 0 & $7(4)$ \\
Forepaw & Pre & 0 & 0 & $9(2)$ & $1(3)$ \\
& Post & 4 & 0 & 0 & $6(4)$ \\
& Pre & $1(2)$ & $9(3)$ & 0 & $(1)$ \\
\hline
\end{tabular}



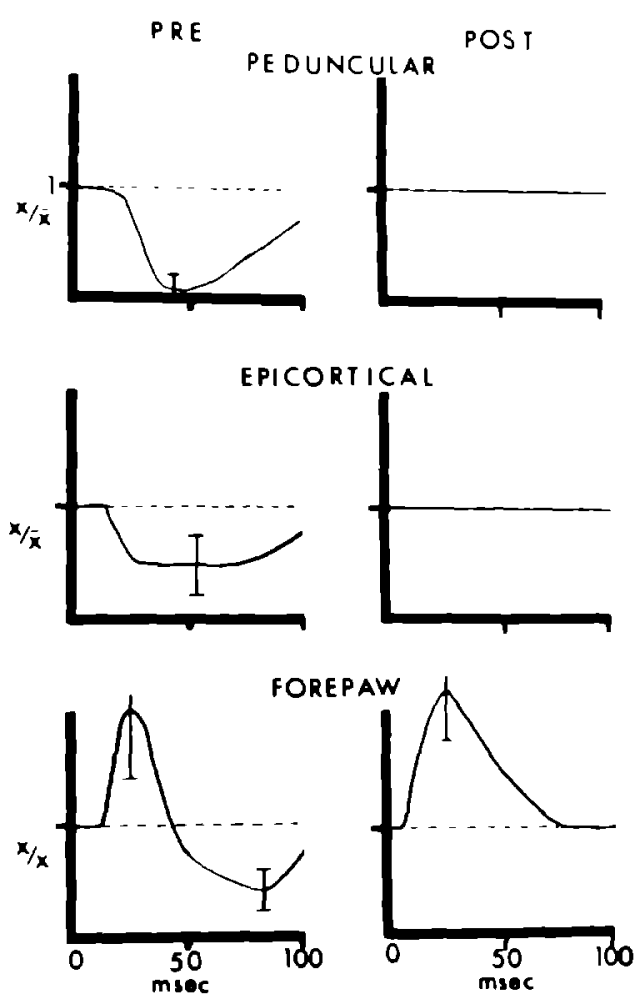

Fig 3 Post-stimulus average responses of $10 \mathrm{PT}$ neurons pre- and post-penicilin The ordinate gives the averaged response, calculated by first normalizing the spike count per $10 \mathrm{msec}$ tıme bin by dividing by the average spontaneous splke count per $10 \mathrm{msec}$ time bin, for that neuron. These normalized values were then averaged to generate the plots shown, where no effect on spontaneous discharge is thus 1 The standard errors of the mean are vertical bars, indicated only at the point of maximal deviation from no effect for clarity

of the sample) responded to peduncular stimulation with a short latency burst of spikes. The latency to this excitation (determined from histograms calculated as described for the PT cell above) was less than the latency to the SN-wave peak amplitude, indicating possible involvement of those neurons in the generation of the $\mathrm{SN}$-wave, and hence, possible involvement in recurrent inhibitory pathways.

The responses from one of these B-NPT cells with short latency excitation in response to peduncular stımulation are given in Fig. 4, and histograms calculated for this neuron are

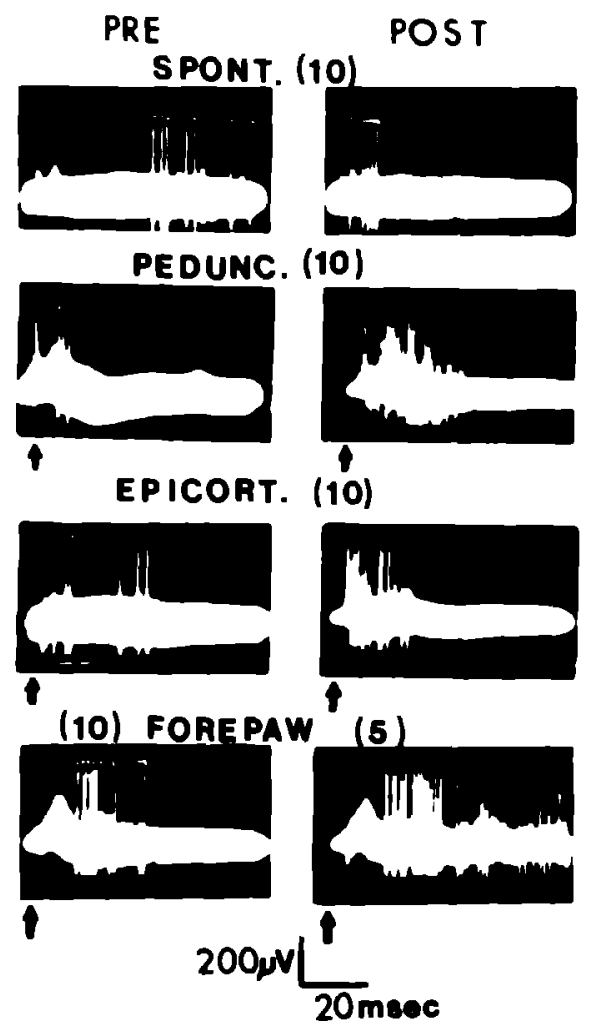

Fig. 4 Post-stimulus responses of a sample B-NPT neuron (discharge marked by dots) pre- and postpenicillin. The number of superımposed sweeps per frame is indicated in parentheses. Abbreviations are as in Fig 1 Stimulus delivery is indicated by the arrow.

shown in Fig. 5. Using the same criteria as tor PT cells, it can be seen from Fig. 4 (and more clearly from the histograms in Fig. 5) that this neuron had a strong excitatory response to peduncular, epicortical and forepaw stimulation pre-penicillin, and these excitatory responses were also observed post-penicillin. In fact, excitatory deviations from mean spontaneous activity were even greater postpenicillin (when assessed as 'multiples of the standard error'). In spite of possible involvement of these 30 neurons in inhibitory pathways, a maintained or enhanced excitabllity (as illustrated in the example) was typical (Fig. 6). The remaining 14 B-NPT cells were also more likely to exhibit an excitatory 

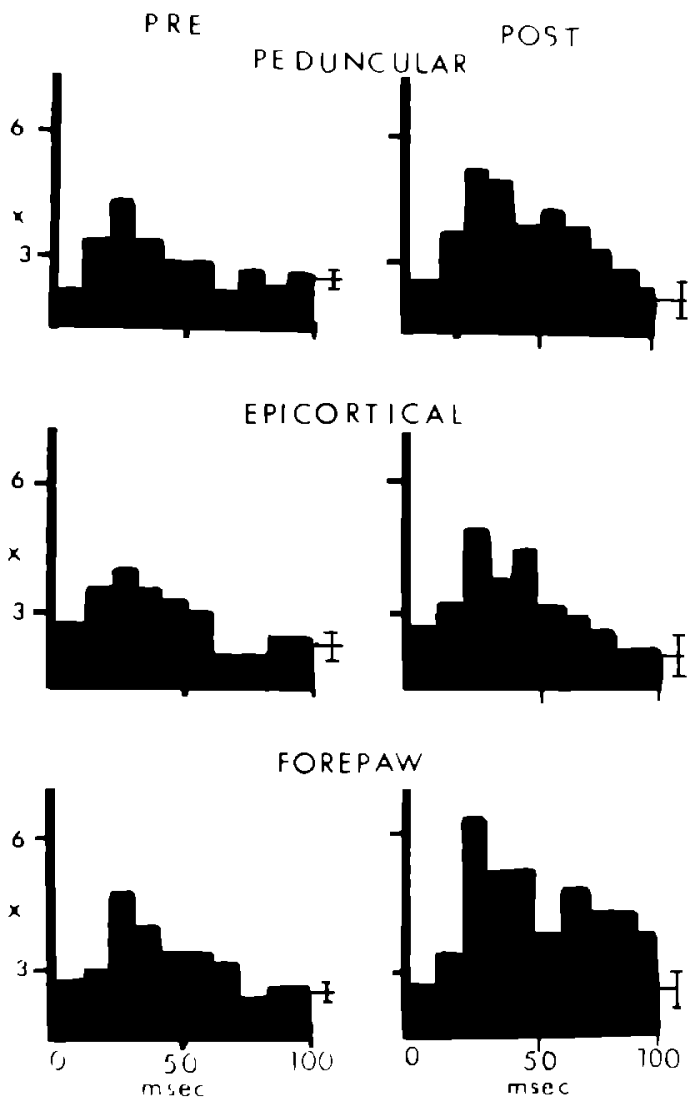

Fig 5 Post-stımulus histograms pre- and post-penicillin derived for the B-NPT cell shown in Fig 4 The spontaneous rate and standard error of the mean are indicated at the right (spontaneous rate $=1.4$ pre-, 12 post-penicilin) Note that excitatory responses of the neuron are maintained following development of the penicillın focus

response to any of the 3 stimul post-penicillin, as can be seen from the summary given in Table II. Thus, excitatory responses of B-NPT cells observed pre-penicilln were maintained and often enhanced post-penicullin, and excitatory responses were more commonly observed post-penicillin than pre-penicillın.

\section{NPT cells}

While PT cells and B-NPT cells were faurly consistent in their response patterns to the various stimul, no such uniformity was observed in the responses of the NPT cells. This
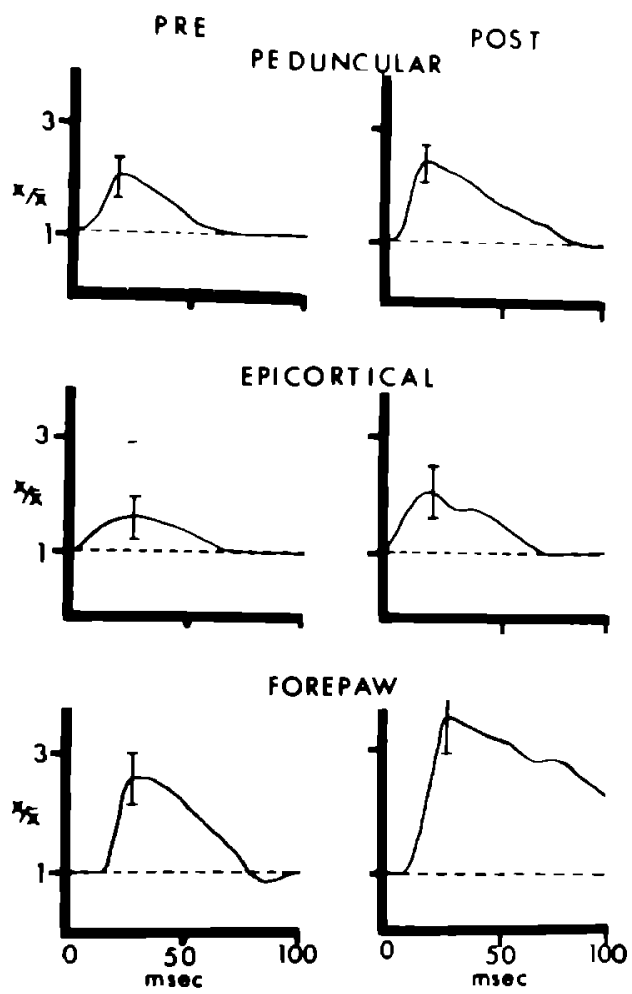

Fig 6. Post-stimulus average responses of $30 \mathrm{~B}-\mathrm{NPT}$ neurons which exhibited short-latency excitatory response to peduncular stimulation. Calculations were as for Fig. 3, and standard errors are again indicated by vertical bars

is not altogether surprising, since the NPT cells are probably a heterogeneous group which may include long and short association neurons, commissural neurons and some PT cells whose axons were simply too distant from the peduncular stimulating electrode to be antidromically activated. For these cells also, inhibition was the most commonly observed effect of peduncular or epicortical stimulation, and they all exhibited an initial excitation in response to forepaw stimulation. Subsequent to penicilin application, excitatory effects of the stimuli were more commonly observed. Excitation in response to forepaw stimulation was enhanced post-penıclllin, both in respect to the number of spikes generated by the stimulus and in the duration of the enhanced firing period. However, the 


\section{TABLE II}

Response characteristics of B-NPT cells. Data are tabulated as number of cells in each category. Definitions of categories are as in Table I

\begin{tabular}{llllrr}
\hline Stimulation & & Excit & Excit $\rightarrow$ inhib & Inhib & No effect \\
\hline Peduncular & Pre & 36 & 3 & 5 & 0 \\
& Post & 44 & 0 & 0 & 0 \\
Epicortical & Pre & 20 & 0 & 11 & 13 \\
Forepaw & Post & 41 & 0 & 0 & 3 \\
& Pre & 39 & 4 & 0 & 1 \\
& Post & 44 & 0 & 0 & 0 \\
\hline
\end{tabular}

TABLE III

Response characteristics of NPT cells. Data are tabulated as the number of cells in each category Definitions of the categories are as in Table I

\begin{tabular}{llllrl}
\hline Stımulation & & Excit. & Excit $\rightarrow$ inhıb. & Inhıb & No effect \\
\hline Peduncular & Pre & 2 & 2 & 14 & 0 \\
& Post & 9 & 0 & 1 & 8 \\
Epicortical & Pre & 5 & 3 & 10 & 0 \\
Forepaw & Post & 10 & 0 & 0 & 8 \\
& Pre & 11 & 7 & 0 & 0 \\
& Post & 18 & 0 & 0 & 0 \\
\hline
\end{tabular}

fact that the identity of the NPT cells is uncertain precluded their usefulness in drawing conclusions regarding the probable mechanisms underlying penicillin epileptogenesss. The response characteristics of the NPT cells are summarized in Table III.

\section{Discussion}

The purposes of this study were 2 -fold. The first goal was to verify or refute the hypothesis advanced by Van Duijn et al. (1973) that inhibition is functionally less effective at PT cells in mature eplleptic foci when compared with PT cells in normal cortex. The present observations clearly confirm this hypothesis. Since almost all PT cells are inhibited by peduncular stimulation prior to pentcllin application, yet none are inhibited in the penicillin focus, strong conclusions may be drawn regarding the population of PT cells from which the sample was taken. The popu- lation of PT cells is large compared to the sample size (10) and we can view these data as a binomial distribution sampled with replacement, where the two alternatives are (1) inhibition is preserved in the penicillin focus, and (2) inhibition is not preserved in the focus. From a standard table giving $95 \%$ confidence levels for such a sampling, we see that the observed effect, loss of the inhibitory effect of peduncular stimulation on PT cell discharge, can be expected to occur in at least $69 \%$ of all PT neurons, the population sampled. If the similar effects upon responses of neurons only recorded post-penıcillin are included, increasing the sample size to 14 , the inhibition resulting from peduncular stimulation would be expected to be lost postpenicillin in at least $76 \%$ of the general population of PT cells. Loss of inhibition on PT cells in a penicillun focus can now be regarded as an established fact.

A schematic diagram of circuitry in the precruciate cortex is given in Fig. 7, with sug- 
gested mechanisms leading to reduced mhibition at PT neurons. Alternative 1 is that penicillin acts on PT axons, their recurrent collaterals or the synapses of those collaterals onto inhibitory interneurons. The observation that excitatory responses of B-NPT cells, likely interneurons, to peduncular stimulation persist in the penicullon focus argues against this alternative. Also, inhibition in response to epicortical stimulation was decreased in the penıcilln focus, a finding which would not be expected if effects on pyramidal cell processes were the major effect of penicillin. The second alternative is that the responsiveness of unhibitory interneurons is decreased in

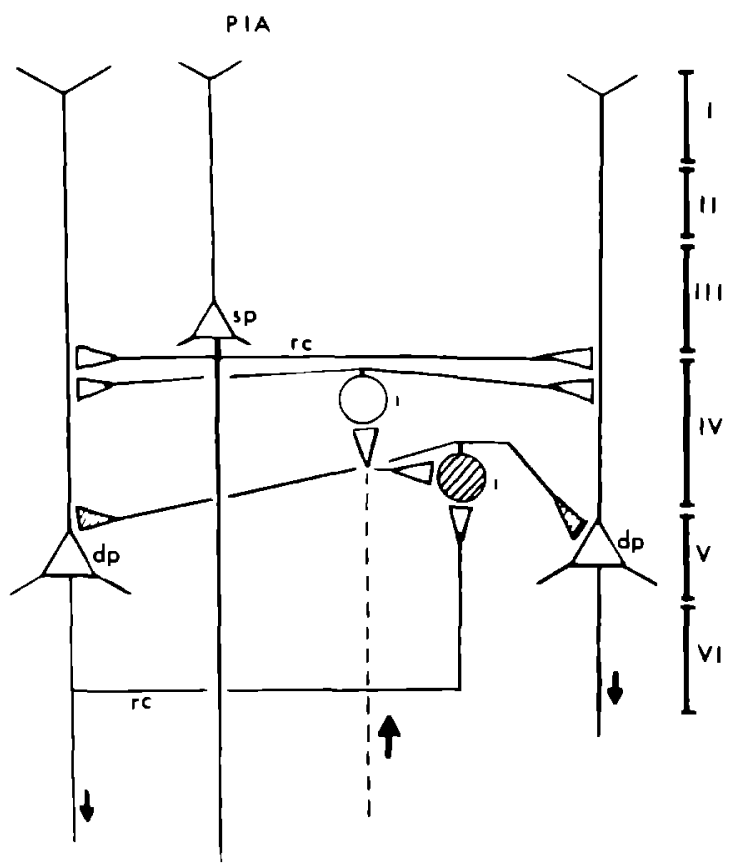

Fig. 7. Schematic diagram of neuronal circuitry in layers of pericrucıate cortex. dp, deep pyramidal tract cell; sp, superficial pyramidal tract cell; $i$, interneuron, rc, axon recurrent collaterals. The deep lying pyramidal neuron has a recurrent excitatory contact on an inhibitory interneuron, thereby mediatıng recurrent inhibition. Inhibitory interneurons and synapses are shaded. The dashed line indicates afferent input. Note the recurrent excitatory contacts of superficial pyramidal neurons. Cells whose discharges were recorded were probably located primarily in layers IV and V penicillin foci, and that this results in decreased effectiveness of recurrent inhibition. However, the class of neurons most likely to represent inhibitory interneurons, the B-NPT cells with short latency excitatory responses to peduncular stimulation (Stefanis 1969), show maintained excitatory response to peduncular stimulation in the penicillin focus. In fact, the excitatory response often shows greater deviation from mean spontaneous activity (measured as a multiple of the standard error) in the penicillin focus than in normal cortex, as illustrated by the example in Fig. 4 and also the averaged responses in Fig. 6. Thus, the second alternative is similarly unlikely to hold.

The thurd alternative is that penicillın acts at the inhibitory synapses onto PT cells, blocking or reducing effectiveness of transmission. The data are consistent with this alternative, as inhibitory effects were diminished in the penicillin focus regardless of the stimulus which initially generated the inhıbition. This would be expected if the deficit in the inhibitory pathway was at a final common point, the inhibitory synapse. In support of this, it has been demonstrated that iontophoretıcally applied penicillin will reversibly reduce the inhibitory effect of GABA upon discharge of neurons in both spinal cord and pericruciate cortex of cats (Curtıs et al. 1972).

The fourth alternative is that rather than acting specufically on inhibitory pathways, penicillin acts to enhance excitatory input, thereby reducing the effectiveness of inhibitory input to the PT cells. This could be accomplished through a direct effect of penicillın on presynaptic terminal membrane, as has been demonstrated to occur in both invertebrate preparations (Futamach 1 and Prince 1975) and isolated mammalian nervemuscle preparations (Noebels and Prince 1977). Further, antidromic spiking, elicitable by an orthodromic action potential, has been observed in mammalian nerves subsequent to application of penicillin in the terminal region of the neuron, both in isolated preparations 
(Noebels and Prince 1977) and in thalamocortical projection neurons (Gutnıck and Prince 1972). Indeed, excitatory effects of forepaw stımulation often did result in greater deviation from spontaneous activity of PT cells in penicillin foci when compared to normal cortex, as is apparent in Fig. 3. However, this appeared to be a result of a delayed peak of excitation rather than a faster rise in the deviation away from spontaneous activity. This would be expected if longer latency inhibitory input normally served to damp excitatory responses, and the unhibitory control feature was lost or greatly impaired in the penicillin focus.

The most likely mechanism for the epleptogenicity of penicillin is a combination of alternatives 3 and 4 . That excitatory pathways in the uppermost 3 layers of cortex are crucial to epileptogenic effects of penicillin was verified by Reichenthal and Hocherman (1977) in an attempt to determine the minimum area of rat cortex which could sustain epileptıform actıvity. They found that subpial incisions dividing an active focus into two or more regions which were each less than the critical area $\left(0.5 \mathrm{~mm}^{2}\right)$ rendered each subfocus inactive, even when the cuts were restricted to layers I, II and III of the cortex with no damage discernible histologically in deeper layers. Thus, recurrent and feed-forward excitatory pathways appear to be crucral to development of epileptiform actıvity.

In conclusion, a functional decrease in recurrent inhıbition has been demonstrated at the PT cell level subsequent to penicillın application to the surface of precruciate cortex. Some degree of caution should be maintained in the interpretation of these observations as they relate to the mechanisms underlying the epileptogenicity of penicllin, and more generally, the mechanısms underlying epileptiform activity in cortex. Since chloralose anesthesia as used in these experiments does alter neuronal responsiveness, these observations should now be confirmed in the unanesthetized preparation. However, in no case in the present experiments did interictal spiking develop except in the localized area surrounding the site of penicillin application. Furthermore, since the level of chloralose anesthesia probably remained essentially constant throughout the course of the experiment, comparisons of neuronal response properties pre- and post-penicllin remain valid, even if the baseline responsiveness of the neuron differs somewhat from the unanesthetızed case.

The observed decrease in recurrent inhibition is not due to general reduced responsiveness of PT cells to synaptic input, since forepaw stimulation elicited excitatory responses are maintained in the penicillin focus. The decreased inhibition is most likely due to a direct effect of penicillin upon the inhibitory synapses onto PT cells, possibly through interference with a GABA mediated inhibition. Th1s decreased inhibition, however, probably requires intact recurrent excitatory pathways before epleptiform activity can be sustained.

\section{Summary}

A previous study indicated that the early surface negative component (associated with recurrent inhibition) of the evoked potential recorded from cat pericruciate cortex, subsequent to pyramidal tract stımulation, was altered after application of penicillin to the cortical surface (Van Duinn et al. 1973). This suggested that decreased effectiveness of recurrent unhibition might be the basis for epileptogenicity of penicllin.

To verify that recurrent inhibition is functionally decreased in the penicillin epileptic focus and to assess alternative sites for penicillın action, this phenomenon was investigated at the cellular level. Neurons were recorded extracellularly and response to stimuli monitored throughout the transition from normal cortex to epileptogenic cortex. Stimulı employed were peduncular stimulation (to test recurrent inhibitory pathways), epicort1cal stimulation (to test inhibitory pathways, 
bypassing the recurrent collateral system), and forepaw footpad shock (to test the responsiveness of neurons to afferent input).

In normal cortex, PT cells were inhibited by peduncular or epicortical stimulation and excited by forepaw stimulation, with the excitation followed by a period of inhibition. In the penicillin focus, inhibition was not observed in response to any of the 3 stimuli, and the excitatory response to forepaw stimulation was maintained.

The bursting non-PT cells, most likely candidates for interneurons, exhıbited excitation in response to peduncular and epicortical stimulation, consistent with involvement in inhıbitory pathways. Nonetheless, in the pen1cullin focus, excitatory response to peduncular and epicortical stımulation was maintained. Excitatory response to forepaw stimulation was also maintained in the penicillin focus.

The results demonstrate a loss of effectiveness of recurrent inhibition measured at the PT cell body in the penicillin focus. Further, the reduction in inhibitory feedback occurs in conjuction with maintained or enhanced excitability of the neurons which are most likely candidates for inhibitory interneurons. Thus, penicillin is most likely exerting its effect at the inhibitory synapses onto PT cells in the cortex, thereby allowing excitatory input to have greater influence on neuronal firing.

\section{Résumé}

Inhıbıtion dans les foyers épileptıques induit par pénicilline

D'après une étude antérieure, la composante précoce surface négative (associée à l'inhıbition récurrente) des potentiels évoqués enregistrés au niveau du cortex péricrucié du chat, à la suite d'une stimulation du tractus pyramidal, est altérée après application de penicilline à la surface du cortex (Van Duijn et al. 1973). Ceci suggère que la diminution d'efficacité de l'inhibition récurrente pourrait être à la base du caractère épileptogène de la penicillıne.

Pour vérifier que l'inhıbition récurrente est fonctıonnellement dimınuée au niveau des foyers épileptiques à la pénicilline et pour établir d'autres points d'actıon de la pénicilline, ce phénomène a été étudié au niveau cellulaire. Des neurones ont été enregistrés de façon extra-cellulaire et la réponse à des stimuli a été contrôlée au cours de la transitıon du cortex normal au cortex éplleptogène. Les stimuli utılisés ont été la stımulation pédonculaire (pour tester les voies inhibitrices récurrentes), la stimulation épıcorticale (pour tester les voies inhıbitrices, dérivant du système collatéral récurrent), et le choc à la plante du pied (pour tester la réactivité des neurones aux afférences). Dans le cortex normal les cellules PT ont été inhıbées par la stımulation pédonculaire ou épıcorticale et excitées par la stimulation de la plante du pied, cette excitation étant sulvie par une période d'inhibition. Dans le foyer épleptogène, l'inhibition n'est observée en réponse à aucune des trois stımulatıons, et la réponse excitatrice à la stimulation de la plante du pred se maintıent. Les décharges des cellules non-PT, plus vraisemblablement des interneurones, montrent une excitation en réponse à la stımulation pédonculaire et épıcorticale, confurmant que les voies inhibitrices sont impliquées. Néanmoins, dans le foyer épileptogène, la réponse excitatrıce à la stımulation pédonculaire et épıcortıcale se maintient. La réponse excitatrice à la stımulation de la plante du pied se maintient également dans le foyer à la pénıcilline.

Ces résultats montrent la perte d'efficacité de l'inhibition récurrente mesurée au niveau du corps des cellules PT du foyer à la pénicillıne. De plus, la réduction du feedback inhıbiteur survient en même temps que le maintien ou l'augmentation de l'excitabilité de neurones qui sont plus vraisemblablement des interneurones inhibiteurs. Aınsi, la pénicilline exerce très probablement ses effets au nıveau des synapses inhıbitrices quı vont aux cellules PT du cortex, permettant alors à l'afférence 
excitatrice d'avour une influence plus grande sur la décharge neuronique.

\section{References}

Curtıs, D R., Game, C.J.A., Johnston, G.A R., McCullock, R M. and MacLachlan, R.A. Convulsive action of pentcillin. Brain Res., 1972, 43. 242245.

Dichter, M. and Spencer, W.A. Penicillın-ınduced interictal discharges from cat hippocampus. II. Mechanisms underlyıng orıgin and restriction J. Neurophysıol., 1969, 32 663-687.

Futamachi, K.J. and Prince, D.A. Effect of penicillin on an excitatory synapse. Brain Res., 1975, 100 589-597.

Gutnıck, M.J. and Prince, D.A Thalamocortical relay neurons antidromic invasion of splkes from a cortical epileptogenic focus. Science, 1972, 176. $424-426$.

Humphrey, D R., Re-analysis of the antidromic cortical response. I. Potentials evoked by stimulation of the isolated pyramidal tract. Electroenceph. clin. Neurophysiol., 1968, 24 116-129.

Jasper, H.H. and Ajmone Marsan, C., A Stereotaxic Atlas of the Diencephalon of the Cat. National Research Council of Canada, Ottawa, 1954.

Krnjević, K., Randic, M. and Straughan, D.W. An inhıbitory process in the cerebral cortex. J Physiol. (Lond.), 1966a, 184 16-48.

Krnjević, K., Randic, M. and Straughan, D W. Nature of a cortical inhibitory process. J. Physiol. (Lond.), $1966 \mathrm{~b}, 184 \quad 49-77$.

Matsumoto, H. and Ajmone Marsan, C. Cortical cellular phenomena in experimental epilepsy. interictal manıfestations. Exp. Neurol., 1964, 9' 286-304. Matsumoto, H., Ayala, G.F. and Gumnit, R.J. Neuro- nal behavor and triggering mechanisms in cortical epileptic focus J. Neurophysiol., 1969, 32 688703.

Noebels, J.L. and Prınce, D.A. Presynaptic origin of penicillin afterdischarges at mammalian nerve terminals. Brain Res., 1977, 138: 59-74.

Pedley, T.A. and Noebels, J.L. Anatomic localization of $\mathrm{C}^{14}$-penicillin in experımental focal epılepsy. Neurosc1. Abstr., 1976, 2: 253.

Prince, D.A., Inhibition in 'epuleptic' neurons. Exp. Neurol., 1968, 21. 307-321.

Prince, D.A., Electrophysıology of 'epıleptic' neurons: spike generation. Electroenceph. clin. Neurophysiol., 1969, $26 \quad 476-487$.

Reichenthal, E, and Hocherman, S. The critıcal cort1cal area for development of penicillın-induced epilepsy. Electroenceph. clin. Neurophysılol, 1977, 42: 248-251.

Renaud, L.P. and Kelly, J.S. Identification of poss1ble inhibitory neurons in the pericruciate cortex of the cat. Brain Res., 1974a, 79 9-28.

Renaud, L.P. and Kelly, J.S. Simultaneous recordings from pericruciate pyramidal tract and non-pyram-dal tract neurons response to stimulation of inhıbitory pathways. Brain Res., 1974b, 79 29-44.

Stefanis, C. Interneuronal mechanisms in the cortex. In: M.A.B. Brazier (Ed.), The Interneuron. Univ. of Calif. Press, Los Angeles, Calif., 1969: 497526.

Stefanis, $\mathrm{C}$ and Jasper, $\mathrm{H}$ Recurrent collateral unhibition in pyramidal tract neurons. J Neurophysıol, 1964, 27 855-877.

Van Duijn, H., Schwartzkroin, P.A. and Prince, D.A. Action of penicillin on unhibitory processes in the cat's cortex. Brain Res., 1973, 53. 470-476.

Walker, A.E. and Johnson, H.C. Convulsive factors in commercial penicillin. Arch. Surg., 1945, 50 $69-73$. 